\title{
WORKPLACE SAFETY CHALLENGES OF COVID-19 PANDEMICS: CASE OF SLOVAKIA
}

\author{
Silvia Capíková ${ }^{1}$ \\ Mária Nováková ${ }^{2}$ (iD)
}

DOI: https://doi.org/10.31410/LIMEN.2020.65

\begin{abstract}
Public health laws designed to protect the life and health of people have an impact on working conditions as a significant social determinant of health. Laws designed to reduce the spreading of COVID-19 also had an impact on the organization of work. Legal research methods were used to analyse the regulatory framework for occupational health in Slovakia since the COVID-19 pandemics outbreak on March 6 ${ }^{\text {th }}, 2020$, and to analyse how the obligations and rights of employers and employees have changed. This paper also examines emerging issues, such as employees' privacy and it explores the role of the external environment in safety management and leadership. New regulations passed to control spreading at workplaces strengthened the position of employers in surveillance of antipandemic measures. Pandemics mainstreamed the role of law as a public health tool. Sharing experiences across sectors of the economy and countries can be helpful to define good practices and their implementation into legislation.
\end{abstract}

Keywords: Safety leadership, Labour law, Health law.

\section{INTRODUCTION}

lovak Republic registered the first patient hospitalized with COVID-19 on March 6, 2020. The emergency situation related to COVID-19 in Slovakia was announced by the Government on March 11, 2020, the same day when WHO Director-General characterized COVID-19 as a pandemic. Novel coronavirus disease was named COVID-19 on 11 February 2020 by WHO. (WHO, 2020) In March, the COVID-19 disease, its spreading, lethality and impact on human health, diagnostics, treatment were unknown and all countries worldwide are fighting with it since then. What was recommended by WHO experts were the isolation of the sick and the suspected (quarantine), reduction of opportunities and density of interpersonal face-to-face contacts, wearing face masks to reduce aerosol from breathing, washing hands, disinfection.

By a resolution under Constitutional Act No. 227/2002 Coll. on the security of the state, which allows limiting rights and freedoms of citizens for a certain period concerning a principle of proportionality (Burda, 2020), emergency measures were introduced quickly by the government, restricting the mobility of people by curfew and shutting of non-essential shops and services. The measure of the Public Health Authority (hereinafter as PHA) in Case of Public Health Thread No. OLP/5453/2020, introduced since 24.3.2020 a ban on movement of persons in an interior of buildings without coverage of mouth and nose by protective equipment such as facemask, shawl or scarf. Curfew was limited to the borders of the district, and restrictions

$1 \quad$ Faculty of Medicine, Comenius University in Bratislava, Špitálska 24, 81372 Bratislava, Slovak Republic

2 Faculty of Law, Comenius University in Bratislava, Šafárikovo námestie 6, 81000 Bratislava, Slovak Republic 
included all non-essential activities, with few exemptions, e.g. necessary grocery or transport to a health care provider. Limitation of freedom of movement included closed state borders for most of transport and workers migration. The curfew was gradually eased during May and Jun, as statistics of the positively tested cases were decreasing. In July, state borders were open again for transport and employment migration, but also for holidays, with the recommendation not to travel to certain countries on the list of most affected countries - following EU strategy. During so called "first wave", the number of positively tested inhabitants and registered deaths associated with COVID-19 was rather low. In September 2020, the country experienced community spreading and continuous exponential growth. The Slovak government has declared again a national state of emergency on Oct 1, 2020, which was extended until the end of the year 2020.

Labour law and health law in Slovakia overlap in the field of occupational health and safety. Although legislation distinguishes jobs and workplaces based on the extent of exposure to health risk factors many years yet, COVID-19 brings challenges to the field (e.g. ned to define the status of essential and non-essential workers, front-line workers, etc.). The main research question studied is, how the pandemic was reflected by the regulatory framework, how employer and employees' rights and duties had changed to control and hamper workplace spreading.

\section{DEVELOPMENT OF LEGISLATIVE FRAMEWORK OF WORKPLACE SAFETY}

Labour law plays a strong protective function, e.g., the Labour Code contains many provisions that give women more protection in the case of pregnancy and maternity than is provided to a comparable employee (Hamul'ák et al, 2020). The baseline national legislation focusing on occupational health in Slovakia is the Act No 311/2001 Coll. the Labour Code, a special Act No 125/2004 Coll. on occupational health and safety and Act No 355/2007 Coll. on public health, Ordinance of the Government No. 83/2013 Coll. on the protection of occupational health against hazards related to working with exposition to biological factors, and Ordinance of the Government No 395/2006 Coll. on minimal requirements on provision and use of personal protective equipment at work. The basic laws are followed by decrees of The Ministry of Labour, Social Affairs and Family of the Slovak Republic and by other, mostly technical regulations.

Based on $\S 5$ of the Act No. 124/2006 Coll. on Occupational Health, the employer has to perform in accordance with general principles of prevention in the adoption of any measures necessary for occupational health and safety assurance, including assurance of information, education and organization of work and equipment. Based on this mandatory duty, an employer can ask an individual employee to undergo a preventive check-up, or ad hoc testing for COVID-19, etc.

Amendment to the Labour Code by Act No 66/2020 of April 2, 2020, since April 4 introduced new $\S 250 \mathrm{~b}$ that relates to the situation during the period when measures on prevention and combating contagious diseases anti-epidemic measures or measures on protection of public health imposed by the authorized body are in force. Under section 2, the employer has the right to order home office in an employee's household. Also, the employee has an explicit right to work in his household, if the character of work allows such regimen and if there are no known serious operational reasons not allowing work from the household.

Amendment to the Act 124/2006 Coll. on Occupational Health by Act No 66/2020 of April 2, 2020, since April 4 introduced new $\S 39$ i about postponing of some information duties of an 
employer to the employee, but stating that employer still should provide any information necessary for occupational health to employees to protect employee health.

Since May 21, 2020, amendment No 125/2020 to Act No 355/2007 on public health suspended during the crisis some duties of the employer, such as regular work-related medical fitness assessment of employees for prevention of health-related diseases, but there is an exemption: Employers has mandatory obligation to ensure all measures to decrease exposition of employees and inhabitants to physical, chemical, biological or other workplace factors to a minimum level, or to the level defined by specific regulations. Explicitly, new legislation states that all subjects have legal duty to act in accordance with Measures in Case of Public Health Thread by the Public Health Authority.

Measure of the Public Health Authority in Case of Public Health Thread No. OLP/6911/2020 from 28.08.2020 imposed since September 1, 2020 obligation to employers to control the duty of an employee to home quarantine and testing. The employer must ask each employer to show a certificate about staying in home quarantine and negative result of RT-PCR on COVID-19, if employer has a knowledge and reasonable suspicion that he or she was during last 14 days abroad and any of defined exemptions is applicable in terms of Measure of the Public Health Authority in Case of Public Health Thread No. OLP/6850/2020. Employee also had a duty to register when crossing borders into the Slovak Republic and has obligation to show to the employer that he or she did not cross the border in the last 10 days, depending on the country from which he or she came, with some exemptions (e.g. for people who live near the borderline and work across the border). In case that an employee does not have above mentioned documents or refuses to show them, there is a new obligation of the employer: 1. to report this event to a regional office of public health authority, and 2. deny entrance to workplace or all facilities of the employer respectively. Based on $\S 56$ section 2 Act on Public Health, an employee can be sanctioned for a misdemeanour with 1659 EUR and besides, the vicarious liability leading to termination of employment can be applied by an employer. If an employer fails to fill above mentioned duties, the liability for an administrative tort can be applied, with financial sanction up to 20000 EUR.

On October 15, 2020 an Act No. 286/2020 Coll. amending Act No. 355/2007 Coll. on public health and other acts, was published and came into force. The main goal of this amending act was to strengthen the position of PHA in creation of regulatory framework, strengthen the legal nature of its regulation by granting a competence to issue Decrees instead of Measures. This amendment also grants a competence of public health authorities to order a measure to employers or service providers about denying entrance into their facilities and access to services without provision of personal data in defined extent (name, birth date, address, signature, phone No.) of entering persons. Such registration shall serve for epidemiological purposes and should be protected and proceeded by the employer or service provider at maximum of 30 days, and can and provided upon request of the PHA. Employers and service providers also have granted legal right to have such "registration" measure from their own decision.

In order to decrease mortality and to avoid economic lockdown, population-wide testing was realized in the edge of October and November. (Pavelka et al., 2020) Slovakia deployed around 20000 medical staff and 40000 non-medical staff including armed forces and volunteers to run the programme, which started with a pilot from 23 to 25 October in few districts with highest prevalence, and was followed by a round of national mass testing on 31 October and 1 November. High prevalence counties were then targeted with a subsequent round on 7 and 8 November. More than five million tests were completed. Anyone who tested positive was asked 
to quarantine for 10 days, along with all members of the same household and their self-traced contacts. Although Slovakia's testing was not mandatory, residents who did not attend were told to stay at home for 10 days or until the next round of mass testing. Those who participated received a medical certificate confirming their infection status, and a negative test certificate was required by employers in order to enter workplaces, while other venues carried out random checks. (Mahase, 2020) National antigen testing programme and details of the curfew had been enacted by Government Resolution No. 678 of October 22, and No. 693 of October 28, 2020.

COVID-19 was also recognized as a specific biological hazard, firstly by a Commission Directive (EU) 2020/739 of 3 June 2020, amending Annex III to Directive 2000/54/EC of the European Parliament and the Council as regards the inclusion of SARS-CoV-2 in the list of biological agents known to infect humans and amending Commission Directive (EU) 2019/1833. The Directive states: "given the absence of effective prophylaxis or treatment for SARS-CoV-2 and the little and uncertain scientific knowledge on its overall consequences on human health, which prevents its clear classification in risk group 3, SARS-CoV-2 would be more correctly classified in risk group 4 in order to ensure the highest possible levels of protection of workers' health and safety, minimising the risks of further infections and deaths, and a possible second wave of infections". On November 24, Commission Directive was implemented into national legislation by Ordinance of the Government No 333/2020 Coll., amending Ordinance of the Government No. 83/2013 Coll. on protection of occupational health against hazards related to work with exposition to biological factors in workplace. Workplaces are divided into several categories based on levels of health hazards. This Ordinance in its Annex No.5 extends the scope of protective measures and defines levels of protection against biological risk factors at workplace, including COVID-19.

Since November 21, 2020, contracting COVID-19 was enacted as work related injury by Act No. 330/2020 Coll. of November 3, 2020 amending Act 461/2003 Coll. on social insurance, confirmed by the employer that the disease is work-related. New $\S 293 f$,e, a states that employees and the defined group of physical persons such as students in professional training, people involved in emergency assistance, volunteers of the National Red Cross Society and etc. in specific situations have right to accident surcharge to the sick compensation within social insurance scheme, if during emergency was acknowledged as sick because of COVID-19 and this disease occurred while the person was working in defined situations, where exist provable contact with this disease or contact with infectious material as a part of this work, and this fact has been confirmed by the employer.

\section{CHALLENGES FOR WORKPLACE SAFETY}

In general, occupational safety hazards are determined by the job and industry characteristics, work equipment and organization of work. Workplace safety is part of management and is impacted by influences from the wider social environment, which is including also legal environment. Ideally, the legal environment should be steady and comprehensive, however, the COVID-19 pandemics made the environment too turbulent and unpredictable and stability of legal order is challenged. In order to hamper the spreading of COVID-19, various regulations were adopted to protect public health and many of restrictive measures were adopted by authorities entered into force within few days or even hours. Their implementation changed organization of work.

The use of COVID-19 related narratives by extreme-right movements across the whole Europe can be observed. Extreme-right movements do not hesitate to abuse popular feelings and even 
feed disguise and anger in the public against anti-pandemic measures, and organize riots to gain popularity and political power. This can be an important factor in compliance with any antipandemic measures. In Slovakia, since spring 2020, several illegal protests and riots were organized, where organizers encouraged people to non-compliance with anti-pandemic measures, even on October 16 and November 17, 2020, at a time of emergency state declared by the government.

Latest GLOBSEC report informed that while the CEE region managed the first wave of COVID-19 in the spring relatively well, the more recent second wave of the pandemic paired with a growing impact of pandemic counter-measures, economic lockdowns and an infodemic is testing the stability of the region. COVID-19 is, indeed, often used as an excuse to inflame simmering internal conflicts and tensions. A survey of GLOBSEC unravelled, that $31 \%$ of Slovak inhabitants bought into COVID-related conspiracy theories including the notion that the pandemic is fake and a tool to manipulate populations, showing the greatest proneness to believe in conspiracy theories in the V4 region. Almost $40 \%$ of respondents believed that Covid-19 does not exist. (GLOBSEC, 2020) However disinformation spreading can be subject of criminal liability in Slovakia (Slovák, 2020), and the investigation is not easy.

Health disinformation is considered a significant issue during 2020, that motivates behaviour of patients in Slovakia, confirmed a survey of the Behavioural and Experimental Economic Team (BEET) established in 2020 at the Ministry of Health of the Slovak Republic. A total number of 1974 physicians answered a questionnaire distributed in September 2020; 71\% of them witnessed they experience disinformation form patients once a week and 38\% daily. Most of the health disinformation physicians are currently facing are about vaccination (72\%) and the new coronavirus (59\%). A survey brought evidence, that health disinformation contributes significantly to non-compliance of patients with treatment plan (e.g. oncological patients), argue with physicians at a consultation, refuse routine vaccination and claiming e.g. that mortality statistics are overestimated or fake. (Sekelský et al., 2020)

We can only agree with Czech lawyer F.Křepelka, who points to individualism in Western society and claims: "The pandemic exposes an uneasy relation between expertise and politics. The anti-epidemic response is inherently political, especially if physicians and other scientists disagree, and the general public has a broad palette of views... Unfortunately, the Covid-19 pandemic escalates existing socio-political tensions, which hinders the pursuit of public health protection as a concretization of public interest." (Křepelka, 2020, p.1)

To achieve compliance with organizational safety policies and mandatory duties, strong leadership is needed. Leadership, as well as compliance are related to the "mindset" of individuals. Disinformation and conspiracy theories, abuse of pandemics for criticism without offering solutions by political opposition and interest groups in society, high dynamics and complexity of regulatory framework, are examples of negative phenomena in social and especially legal environment of organizations with the potential to hamper the realization of anti-pandemic measures, and are very demanding on safety management and leadership.

\section{LAW, SAFETY LEADERSHIP AND MANAGEMENT}

Although employers appear to be primarily responsible for workplace safety assurance, no rule can be effective without the motivation of employees to provide necessary collaboration and follow organizational safety policies. 
According to D. Kritzinger, safety culture is the attitude that exists when everyone recognises and accepts their responsibilities for safety. (D. Kritzinger, in Aircraft System Safety, 2006) Safety culture is an integral part of safety management, which is very developed in certain sectors, such as aviation, nuclear industry and health care organizations. Safety science can be very useful for employers for creation of safety management models. Seminal work was the book by James Reason (1997), recognised worldwide for his "Swiss cheese" model explaining process how hazards lead to adverse outcomes, distinguishing active failures and latent conditions.

Findings of Macchi et al. suggest, that successful risk management in an organization requires: Safety definition - the desired result of safety management, Safety model - the description of how organisation functions and accidents happen, Safety management model - the background assumptions made in an organisation to manage and improve safety, and Safety management system - collection of systematic organisational processes, needed in order to steer the organisation to ensure and develop safety. (2011, p.39)

Macchi et al. (2011) highlighted components to be included in the safety management model in hospital settings but also in other sectors with high demand for safety:

- Management commitment: safety management is successful only if management is truly committed to safety and if it understands its role in promoting and steering safety. In this respect, management shall define the plan for continuous safety improvements etc.;

- Development of a supportive climate: safety management model shall promote an open and non-blaming climate within the organisation. Supportive climate is the precondition for reporting and discussing accidents and for organisational learning;

- Definition of structures for patient safety: safety management models shall clearly set guidelines for system's organisation, resources allocation, responsibility among actors, reporting of events etc.;

- Definition of the role of the patient: if and how the patient can be involved in managing safety has to be addressed in the safety management model;

- Definition of processes: safety management model shall address the way in which things are done and not only what their result is. This includes the development of procedures, technical and non-technical skills, etc.;

- Integration of safety management: safety management model shall define how safety management is integrated with other management functions (occupational safety, economics, information safety, production etc.). (Macchi et al., 2011, p.28 - 29)

This model can be applied beyond healthcare safety, with certain adaptations, such as instead of definition of the role of the ,patient" there can be role of ,client" or ,visitor" or "student". However written documents about tasks and responsibilities can be viewed as boring formalism, clear safety policy can lead to better motivation of involved actors to act safely, and, form the legal point of view, it documents efforts of an employer to act proactively to prevent health risks, especially those related to deadly outcomes such as COVID-19, and fulfil the mandatory duties. Also, in case of non-compliance of an employee, a co-worker or a client or visitor, good workplace safety management system together with educated employees should reduce the risk of contagion and find legally defensible solution in a given situation.

\section{FUTURE RESEARCH DIRECTIONS}

We suppose that majority of people in Slovakia are behaving in accordance with public health measures; however, further research could be useful for better understanding of barriers and 
facilitators of coping of employers and employees with anti-epidemic measures (e.g. size of organization, industry sector etc.).

Anti-pandemic regulations are written in legal terminology, that is unclear to common people, but often to lawyers, too. Legal communication processes should be studied to broaden the knowledge, how employers and common people understand imposed public health law measures, as a necessary step in compliance with such measures.

Law and Economy (L\&E) methodology (used e.g. by Houser et al., 2008) should be used to identify appropriate sanctioning of pathological behavioural patterns related to disobedience of law. Thorough empirical legal research, including health policy analysis, is needed to assess the quality, impact and efficiency of legal regulation and its enforcement.

Comparative legal research is needed, to identify effective legal concepts that can fit to national legal systems, especially taking into account a common statutory law tradition in Europe. Labour law overlaps with public health in field of protection of life and health of people who are employed.

Government members worldwide suddenly turned into public health leaders, attempting to work across sectors to hamper spreading of the virus. Coping with new national health regulations that owners and managers but also workers find very limiting, brings also the question, which type of leadership can be appropriate?

\section{CONCLUSION}

Our study confirmed that labour law in Slovakia imposes a lot of duties to employers to protect employees from health hazards and act proactively, and the legal framework was supplemented by new obligations of employers to hamper the spreading of COVID-19 at workplaces. The research presented suggests, that since the COVID-19 outbreak in Slovakia, governmental regulations and public health measures contributed more to the complexity of legal environment than changes in statutory law in the studied period.

It should be mentioned social threads that COVID-19 imposes on employees, who are suspected or positively tested for COVID-19, who are facing social stigma related to COVID-19 and are often experiencing a significant reduction of income and financial hardships. As it can be expected that new mutations of the virus occur, disease can spread to farm animals (such as minks in Denmark), so the dynamics of legislation can also be rather high in the following months and years. All of this can have an impact on labour relations. Due to COVID-19, it seems necessary to understand the role of law as a public health tool and to integrate research to formulate more precise public health law regulations, minimizing their unintentional adverse impacts.

\section{REFERENCES}

Act No 311/2001 Coll. The Labour Code

Act No. 461/2003 Coll. on social insurance, as amended by act 330/2020 Coll.

Act No 124/2006 Coll. on occupational safety, as amended

Act No 355/2007 Coll. on protection, promotion and support of public health, as amended (Act on public health)

Act No 66/2020 amending Act No 311/2001 Coll. The Labour Code and some other acts. 
Act No 69/2020 Coll. On Emergency measures related to rapidly spreading dangerous contagious human disease COVID-19 in field of health care and amending some acts

Act No 125/2020 amending Act No 355/2007 on public health

Constitutional Act No. 227/2002 Coll. on security of the state at time of war, state of war, state of emergency, as amended

Government Resolution No. 678 of October 22, 2020

Government Resolution No. 693 of October 28, 2020.

Ordinance of the government No 333/2020 Coll. that is changing and amending Ordinance of the Government No. 83/2013 Coll. on protection of occupational health against hazards related to work with exposition to biological factors in workplace

Ordinance of the Government No 395/2006 Coll. on minimal requirements on provision and use of personal protective equipment at work

Measure of the Public Health Authority in Case of Public Health Thread No. OLP/6911/2020

Measure of the Public Health Authority (hereinafter as PHA) in Case of Public Health Thread No. OLP/5453/2020

Measure of the Public Health Authority in Case of Public Health Thread No. OLP/6850/2020

Commission Directive (EU) 2020/739 of 3 June 2020, amending the Directive 2000/54/EC of the European Parliament and of the Council as regards the inclusion of SARS-CoV-2 in the list of biological agents known to infect humans and amending Commission Directive (EU) 2019/1833

Burda, E. (2020). Núdzový stav, obmedzenie zhromažd'ovacieho práva a právne riziká spojené s jeho nerešpektovaním. In Comenius. Odborný blog. November 2020. Online: https://comeniusblog.flaw.uniba.sk/2020/11/15/nudzovy-stav-obmedzeniezhromazdovacieho-prava-a-pravne-rizika-spojene-s-jeho-nerespektovanim/

GLOBSEC. (2020). GLOBSEC Trends 2020: Central Europe, Eastern Europe \& Western Balkans at the Times of Pandemic. Online: https://www.globsec.org/wpcontent/uploads/2020/12/GLOBSEC-TRENDS20_singlepages.pdf

Hamul'ák, J., Freel, L., Nevická, D. (2020). The comparative analysis of women's status in labor relations in modern Slovakia and the Czech Republic. Danube. 11(3), Pp. 214-227.

Houser, D., Xiao, E., McCabe, K. \& Smith, V. (2008). When punishment fails: Research on sanctions, intentions and non-cooperation. Games and Economic Behavior, 62(2), pp.509-532.

Křepelka, F. Právo pandemie covidu-19: náčrt celkového obrazu. Časopis zdravotnického práva a bioetiky/ Journal of Medical Law and Bioethics. 2020, Vol.10, č.2, p. 1-70. Online: http://medlawjournal.ilaw.cas.cz/index.php/medlawjournal/article/view/201/162

Macchi, L., Pietikäinen, E., Reiman, T., Heikkilä, J. \& Ruuhilehto, K. (2011). Patient safety management. Available models and systems. VTT Working Papers 169. Online: http://www.vtt.fi/inf/pdf/workingpapers/2011/W169.pdf

Mahase, E. (2020).Covid-19: Mass testing in Slovakia may have helped cut infections BMJ 2020; 371 :m4761 doi: https://doi.org/10.1136/bmj.m4761

Pavelka, M., Van-Zandvoort, K. Abbott, S. Sherratt,K., Majdan, M., CMMID COVID-19 working group, Inštitút Zdravotných Analýz, Jarčuška, P., Krajčí, M., Flasche, S. \& Funk, S. (2020). The effectiveness of population-wide, rapid antigen test based screening in reducing SARS-CoV-2 infection prevalence in Slovakia. medRxiv (preprint) 2020. doi:10.1101/2020.12.02.20240648.

Reason, J. (1997). Managing the Risks of Organisational Accidents. Aldershot: Ashgate

Sekelský, L., Fehérová, M., Goda, J., Kurinec, L., Holubjaková, D. \& Friedmannová, M. (2020). Dezinformácie v slovenskom zdravotníctve z pohl'adu lekárov. Bratislava: Ministry of Health of the Slovak Republic. Online: https://www.health.gov.sk/?beetprojekty 
Slovák., I. (2020). Niekol'ko poznámok k trestnej zodpovednosti osôb šíriacich konšpirácie v čase pandémie COVID-19. Comenius. Odborný blog. October 2020. Online: https://comeniusblog.flaw.uniba.sk/2020/10/28/niekolko-poznamok-k-trestnejzodpovednosti-osob-siriacich-konspiracie-v-case-pandemie-covid-19/

World Health Organization. (2020). Coronavirus Disease (COVOD-19): Events as they happen. Online: https://www.who.int/emergencies/diseases/novel-coronavirus-2019/events-asthey-happen

\section{ADDITIONAL READING}

Florek, I, Koroncziová, A. \& Zamora Manzano, J.L. (Eds.). Crisis As a Challenge for Human Rights. Bratislava: Comenius University in Bratislava, 2020, 480s. Online: Crisis_as_a_challenge_for_human_rights.pdf (uniba.sk) 